\title{
IDENTIFICATION OF THE CRITICAL CONTROL POINTS IN A FEED MILL: A CASE STUDY
}

\section{IDENTIFICAÇÃO DOS PONTOS CRÍTICOS DE CONTROLE EM UMA FABRICA DE RAÇÃO: UM ESTUDO DE CASO}

\author{
Paulo Carteri Coradi ${ }^{1}$; Adílio Flauzino de Lacerda Filho ${ }^{2}$; José Benício Paes Chaves ${ }^{3}$ \\ ${ }^{2,3}$ Federal University of Viçosa - UFV - Viçosa - Brazil, alacerda@ufv.br, jbchaves@ufv.br \\ ${ }^{1}$ Federal University of Mato Grosso do Sul - UFMS - Chapadão do Sul - Brazil, \\ paulo.coradi@ufv.br
}

\begin{abstract}
Based on the HACCP principles the objective of this work was to identify the critical points of control in a feed mill to real capacity of production at 1,000 ton day, located in the southwest of Brazil. The presence of birds, rodents, insects, mites and fungi in the products, by-products, as well as internal and external areas of the industry were evaluated. The samplings of products and traps installation were the techniques utilized for the control. In addition, the receiving, pre-cleaning, drying and storage of corn, as well as dosage and mixing of feed were characterized the critical steps in the control of contamination. Furthermore, birds and rodents were the main contaminants observed during the production process, however, the high population of insects and fungal colonies found in the products meant the greatest risk of contamination to the final product. In conclusion, the use of Good Storage Practices and Manufacturing, trap installation, as well as intense cleaning and sanitation processes are immediate and efficiencies alternatives in the contamination control in feed mills.
\end{abstract}

Key-words: birds; fungi; insects; mites; rodents.

\section{Introduction}

There are many incidents around the world that show the importance of feed safety in ensuring the safety of human food (COLATORE, 2001). Currently, the stock feed and livestock industries have the highest possible profile in the food supply chain, a situation that is likely to continue into the future. Feed mills are divided into various cost centers, such as receiving, material processing, mixing, pelleting, packaging, warehousing, and loading (REMPE, 1994). The design and construction of feed mills is variable, because of differences in the type and quantity of feed produced and the process flour. Feed is composed of major 
and minor ingredients (SCHOEFF, 1994). A large portion of the feed formulation includes cereal grains (usually ground) and by-products of cereals, legumes, and animals. Minor ingredients include vitamins, minerals, amino acids, fat, molasses, flavor enhancers and antibiotics. Stored-product insects are often associated with feed mills because of warm temperatures in production areas and the availability of cereal ingredients (ROESLI et al., 2003; ARBOGAST et al., 2000).

Since the decade 50 studies are being conducted to identify the presence of contaminations microbiological in the feed mills. RILETT and WEIGEL (1956) surveyed eight feed mills, two flour mills, and one flour and feed mill between October 1954 and March 1955 in Buffalo, NY, by collecting a $12.3 \mathrm{~kg}$ sample from each mill. They reported only the occurrence of insect species. In total, 2,632 insects, representing 23 species, were associated with the 11 mills. Studies have showed that mites thriving at $14 \%$ moisture content and can become serious problems when grain moistures are in the range of $15-18 \%$. This in turn can lead to insect and mold problems. The grain mite can feed on fungi associated with stored grain, Aspergillus sp. being a favorite. Aspergillus flavus is widely spread fungus in nature which can be isolated from kernels of corn, wheat, barley, oats, rice, cotton seed, coffee, fish meal and many other feed stuffs. It is typical for peanut which is infested underground, especially in tropical and subtropical regions.

Fungi produce mycotoxins in the presence of higher moisture, temperature and adequate substratum. Synthesis is highest when water content is above $13 \%$ and temperature is between $24^{\circ} \mathrm{C}$ and $37^{\circ} \mathrm{C}$ (RASANOVICH and SINOVEC, 2005; SINOVEC et al., 2000). The Hazard Analysis and Critical Control Points (HACCP) were elaborated to prevent microbiological, physical and chemical contamination problems (CODEX ALIMENTARIUS, 2004; FAO, 2001; HOORNSTRA et al., 2001). This approach can be applied to all stages of the food process, ranging from production to processing, transport, commercialization in commercial establishments and/or direct utilization by the customer (CORADI et al., 2011a; SCOTT et al., 2006; ROMANO et al., 2005). To implement the HACCP system, it is fundamental to be well informed of the product and the operational procedures related to its processing, allowing for identification of the points where contamination could possibly occur and how to prevent it (BATA et al., 2006; BOLAND, 2001).

Implementation of a program such as HACCP can improve industrial quality through the quality control of raw materials and the industrialization steps of the food, submitting to pertinent legislation and federal inspections, as well as developing products of quality, reliable and certified, with minimal losses and reduced costs (CORADI et al., 2009; YUNG, 
2006; COLATORE, 2001). Given the efficiency of application of HACCP system in the industry in general, and also the low use of the tool of quality control in feed processing units, based on the HACCP principles the objective of this work was was to identify the critical points for microbiology control in feed mill evaluating the presence of birds, rodents, insects, mites and fungi.

\section{Material and methods}

\section{Experimental area}

The experiment was conducted at a poultry feed industry with the capacity of production of 1,000 ton.day ${ }^{-1}$, located in the southwest of Brazil. The evaluation of the presence of birds, rodents, insects, mites and fungi was realized in the internal and external areas of the feed mill, as well in the flow corn production, soybean meal and feed.

\section{Sampling of raw materials and feed processed}

Samples of corn, flours and feed were collected in the receiving, storing, processing, and expedition steps. In the sectors of receiving of the feed mill, the products were sampled within the transport trucks. Samples of products were collected at the exit of the conveyor belts at the entrance of bucket elevators and screw conveyors. Samples were collected before and after storage of corn and soybean meal, the same was done for the stages of pre-cleaning and drying corn. In the industrialization of feed, product samples were collected at the end of grinding, mixing, pelleting and delivery. To collect samples of products in the sectors receiving and storage were used equipments "auger type". The auger-type compounds were used to collect samples of bulk products and the auger-type manual for the products in bags.

In handling equipment product and the stages of pre-cleaning, drying, grinding, mixing, pelleting and delivery, samples were collected at the exit gates. The corn grains transported in trucks were sampled at different points of the load and the number of points was determined by the size of the lot, according to the rules described in BRASIL (1996). In an amount of less than 100 tons of corn, $20 \mathrm{~kg}$ of product was sampled, while quantities of corn above 100 tons, samples of $15 \mathrm{~kg}$ for each 100 tons were collected.

According to BRASIL (1993), the sampling of the vegetable meals was performed with the removal of samples of $10 \mathrm{~kg}$ to 10 tons each. There is no official methodology to describe the sampling procedures of animal meals for use in feed formulation. So, it was decided collected $10 \mathrm{~kg}$ of product to 10 tons each. In all stages of industrialization and 
expedition of feed it was collected a total of $45 \mathrm{~kg}$ sample for each 1,000 t.dia ${ }^{-1}$ processed, following the standards recommended by the Analytical Laboratory Mycotoxicology (LAMIC), Universidade Federal de Santa Maria. All grains samples were homogenized, reduced and divided into three parts using equipment separated. The samples were weighed and properly identified in plastic bags. Feeds, vegetable meals, and animal meals were divided into three parts of a $1 \mathrm{~kg}$ each, and properly identified and packaged in plastic bags. All samples, in triplicate, were sent to the laboratory for physical-chemical and microbiological.

\section{Determination of the water content in the grains corn}

The water content (\% w.b.) was determined in the quality sector, the indirect method, using the meter moisture Geole (G-800) after being calibrated with the official from the oven, set at $103^{\circ} \mathrm{C} \pm 2{ }^{\circ} \mathrm{C}$ for $24 \mathrm{~h}$. Tests were performed with samples of $50 \mathrm{~g}$ in three replicates, according to recommendations contained in Rule for Seed Analysis (BRASIL, 2009). For each sample three replicates were performed.

\section{Determination of the water content in the flours and feeds}

For determination of water content in animal meals, and feed were performed the weighing of the capsules, previously cleaned and dried in an oven at $105{ }^{\circ} \mathrm{C}$ for one hour and cooled in a desiccator until room temperature. A sample of $5 \mathrm{~g}$ was weighed and placed in an oven preheated to $103{ }^{\circ} \mathrm{C} \pm 2{ }^{\circ} \mathrm{C}$ until constant weight (4 hours). After this time, the container was removed from the oven, cooled in a desiccator until equilibrium with the ambient temperature, and held the weight (BRASIL, 1993). For each sample three replicates were performed.

\section{Control of rodents and birds at the feed mill}

The monitoring of rats in the feed mill was accomplished with the installation of traps and application of product "raticide" in the form of "block", distributed by square meter of each section of the feed mill (Table 1). In the same sections, the presence of birds was evaluated. Every two weeks the traps were inspected to verify the presence of signs of rodents as feces, urine, hair, consumed baits, live and dead rodents (MATIAS et al., 2002). The frequency of birds in the sectors was identified by the presence of feces, feathers, live birds and dead birds. 
Table 1 - Distribution of traps for rodent control at the mill

\begin{tabular}{lcc}
\hline Evaluated sectors & Area $\left(\mathbf{m}^{\mathbf{2}}\right)$ & Number of installated traps \\
\hline Portaria (receiving) & 80 & 2 \\
Feed production & 1000 & 25 \\
Hopper of corn & 120 & 3 \\
Hopper of flours & 120 & 3 \\
Storage of corn & 1200 & 30 \\
Storage of flours & 295 & 7 \\
Pre-cleaning of corn & 36 & 1 \\
Drying of corn & 34 & 1 \\
\hline
\end{tabular}

\section{Counting of insects}

The assessment of insects in the products was made by visual counting in $1 \mathrm{~kg}$ of product sampled (LORINI, 2002). The product sample collected from $1 \mathrm{~kg}$ was poured into a table, with artificial lighting, then pulled out with tweezers all the insects and the sample was made to count them. According to LORINI et al. (2002) low infestation was considered to be fewer than 6 insects; medium infestation up to 15 insects; and high infestation over 25 insects for sample of $1 \mathrm{~kg}$.

\section{Counting of mites}

The samples examined were first sieved through stainless steel mesh opening of 0.50 $\mathrm{mm}$ on a sheet of paper to separate the particles of dust mites in the sample. Mites were quantified under a stereomicroscope. All results were expressed in terms of $50 \mathrm{~g}$ of sample (HUGHES, 1976).

\section{Counting of fungi colonies}

The analysis of toxigenic fungi was performed by DHINGRA \& SINCLAIR (1995). Analyses were performed in triplicate and results were expressed as Colony Forming Unit per gram of contaminated products $\left(\mathrm{CFU} \cdot \mathrm{g}^{-1}\right)$. In the process of preparation of the samples was weighed $25 \mathrm{~g}$ in sterile stomacher bag (Seward Stomacher 400 Lab System, England), then mingled with $225 \mathrm{ml}$ of the saline water and peptone $0.1 \%$, yielding so the $10^{-1}$ dilution. After sample homogenization, serial dilutions were performed up to $10^{-4}$ using test tubes with 9.0 $\mathrm{ml}$ of the same diluents. For the seeding process was used the technique of plating on the surface, through the use of medium Batata-Dextrose-Ágar acidified with $10 \%$ tartaric acid to a $\mathrm{pH}$ of 3.5. The material was pipetting to $0.1 \mathrm{ml}$ of each sample dilution in sterile Petri dish 
containing $20 \mathrm{ml}$ of culture medium acidified PDA and a Drigalski loop; spread the inoculums across the medium surface, then incubated at a temperature of $25{ }^{\circ} \mathrm{C} \pm 1^{\circ} \mathrm{C}$ for a period of four days. After this period, the colonies were quantified $\left(\mathrm{CFU} \mathrm{g}{ }^{-1}\right)$.

\section{Hazard Analysis and Critical Control Points (HACCP) system}

The potential dangers were analyzed as for insect presence, fungi and mites in the corn samples, soybean meal, feed, and birds and rodents in the different processing steps of the feed mill. The application of the HACCP system was used, being its is considered the logical sequence described by FAO (2001): identification of critical control point, establishment the critical control limits, monitoring procedures, application of corrective actions, verification procedures, and recording methods.

\section{Results and Discussion}

Table 2 show the critical points observed at the feed mill.

Table 2 - Critical control points in different sectors of the feed mill

\begin{tabular}{lccc}
\hline CCP/Sectors & Hazards & Critical limits & Monitoring \\
\hline CCP1 & Birds & Present or Ausent & Visual - Biweekly \\
Hopper of corn & Rodents & $\leq 5$ average $\geq 29$ & Visual - Biweekly \\
and flour & Insects & $\leq 6$ average $\geq 25$ & Sampling - Biweekly \\
& Mites & Present or Ausent & Sampling - Biweekly \\
CCP 2 & Rodents & $\leq 5$ average $\geq 29$ & Visual - Biweekly \\
Pre cleaning of & Birds & Present or Ausent & Visual - Biweekly \\
corn & & & \\
CCP 3 & Rodents & $\leq 5$ average $\geq 29$ & Visual - Biweekly \\
Drying of corn & Birds & Present or Ausent & Visual - Biweekly \\
CCP 4 & Insects & $\leq 6$ average $\geq 25$ & Sampling - Biweekly \\
Storage of corn & Mites & Present or Ausent & Sampling - Biweekly \\
& Fungi & Present or Ausent & Sampling - Biweekly \\
& Rodents & $\leq 5$ average $\geq 29$ & Visual - Biweekly \\
& Birds & Present or Ausent & Visual - Biweekly \\
CCP 5 & Insects & $\leq 6$ average $\geq 25$ & Sampling - Biweekly \\
Storage of flour & Mites & Present or Ausent & Sampling - Biweekly \\
& Fungi & Present or Ausent & Sampling - Biweekly \\
& Rodents & $\leq 5$ average $\geq 29$ & Sampling - Biweekly \\
& Birds & Present or Ausent & Visual - Biweekly \\
CCP 6 & Rodents & $\leq 5$ average $\geq 29$ & Sampling - Biweekly \\
Feed production & Birds & Present or Ausent & Visual - Biweekly \\
CCP 7 & Insects & $\leq 6$ average $\geq 25$ & Sampling - Biweekly \\
Mash feed & Mites & Present or Ausent & Sampling - Biweekly \\
CCP 8 & Fungi & Present or Ausent & Visual - Biweekly \\
Pellet feed & Insects & $\leq 6$ average $\geq 25$ & Sampling - Biweekly \\
& Mites & Present or Ausent & Sampling - Biweekly \\
& Fungi & Present or Ausent & Visual - Biweekly \\
\hline
\end{tabular}


The numbers of problems associated with food contamination, consumer demands, as well as social and economic aspects related losses in the production of products, make industries, today further enhance the safety and security of food, as much as production itself. The feed mills are examples, and perhaps one of the lines of food production more worrisome in the matters of contamination, since the products are not provided directly to consumers, through a vision of disengagement in production (CORADI et al., 2010). However, this is already ceasing to be true a few years ago; the results of surveys are showing the influence of the whole production chain in the quality of final products for human consumption, such as chicken meat. The presence of insects, mites, fungi, rodents and birds are some of the problems monitored premises of feed mills and lots of stored products. However, a lot of times contamination is present not just in the products, but also in the equipment and in the less usable spaces of the industry.

Figures 1 and 2 are shown the flow diagrams of the receiving, drying, storage and transport processes for corn and flours as well as the industrialization and dispatch processes of the feed, respectively.

Figure 1 - Flow of the receiving and storage of corn and flours

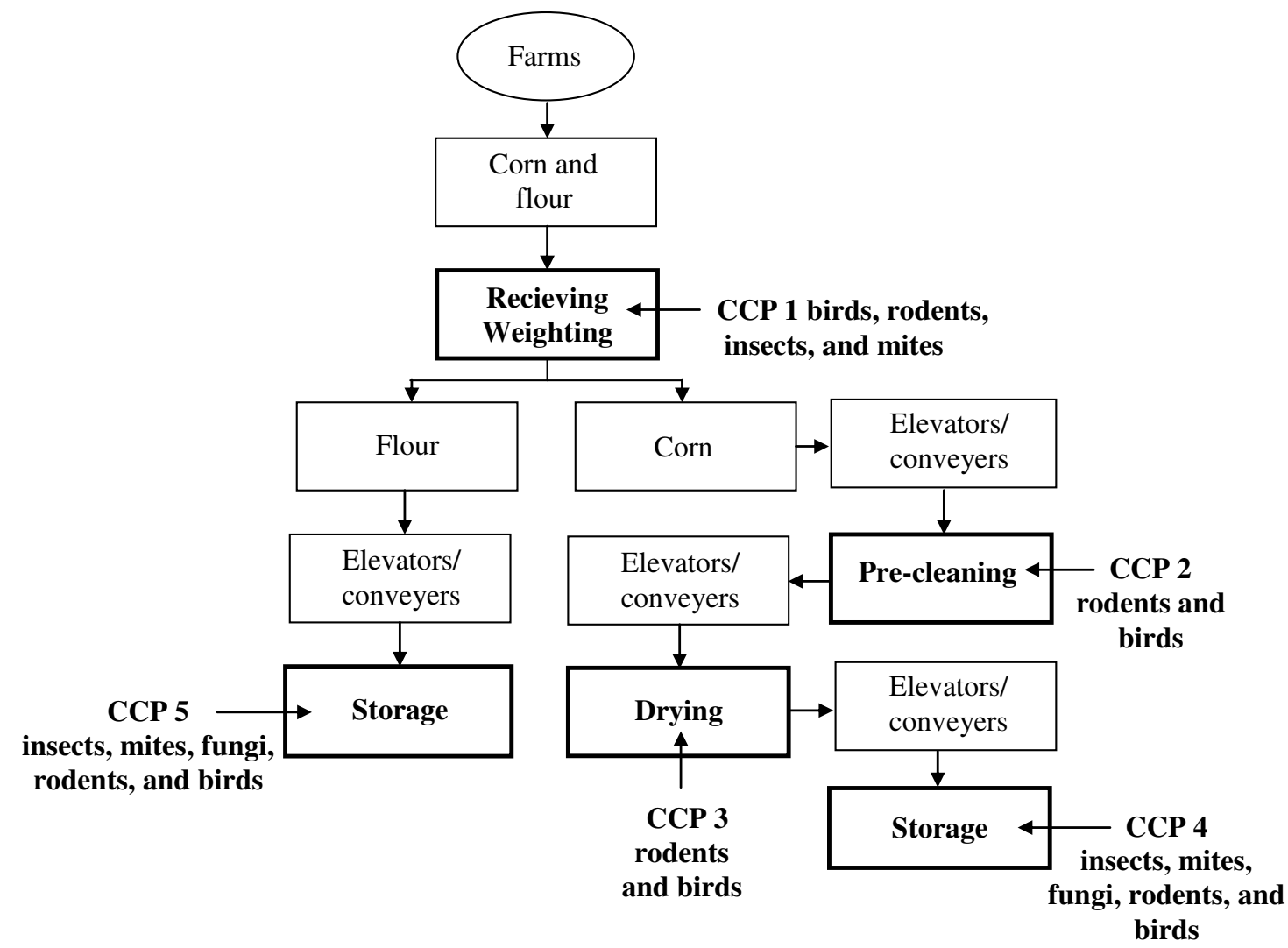




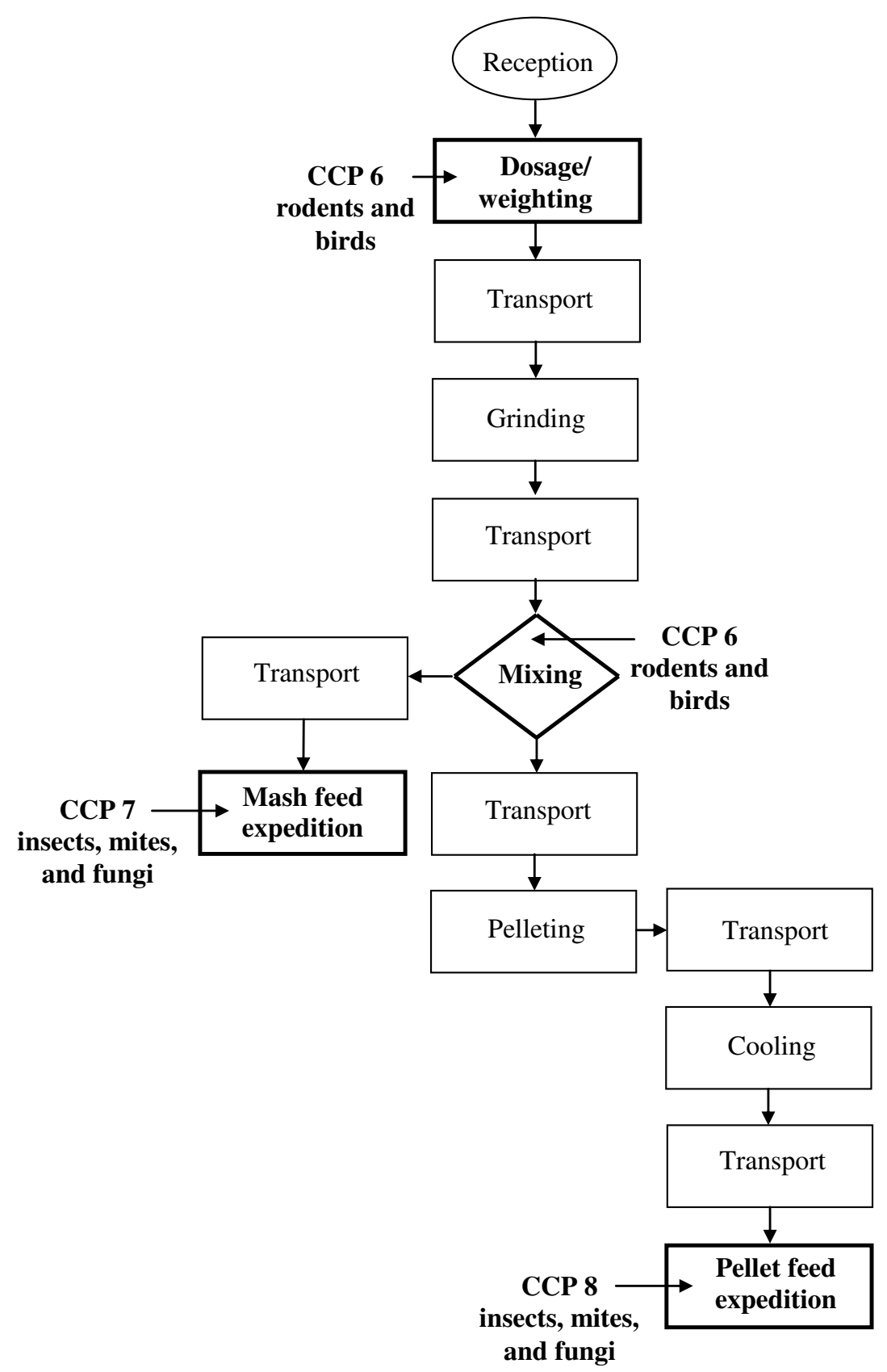

In the samples collected of the different sectors corn was the product with highest microbial infestation followed by soybean meal and feed (Table 3). Fungi colonies and the presence of birds were observed in all samples and sectors evaluated. The frequency of insects, mites and rodents were significant ( $\mathrm{P}>0.05)$, among $50 \%$ and $70 \%$. 
Table 3 - Frequency of samples of corn, flours and feeds infested by insects, mites and fungi

\begin{tabular}{lccc}
\hline & \multicolumn{3}{c}{ Frequency (\%) } \\
\cline { 2 - 4 } Sampling & Insects & Mites & Fungi \\
\hline Sectors of corn $^{\mathrm{a}}$ & 54.14 & 66.67 & 100.00 \\
Sectors of flours $^{\mathrm{b}}$ & 33.33 & 45.83 & 100.00 \\
Sectors of feeds $^{\mathrm{c}}$ & 20.83 & 58.33 & 100.00
\end{tabular}

${ }^{a} \mathrm{~N}^{0}$ corn samples, $n=231,{ }^{b} \mathrm{~N}^{0}$ flour samples, $n=216,{ }^{c} \mathrm{~N}^{0}$ feed samples, $n=252$

The foods in certain environmental conditions, involve temperature and relative air humidity, moisture content and water activity of the products; and they present a typical microbial. Knowing this, it becomes important to know the contamination state of that product and, to take the due precautions in the quality preservation. The activity water (Aw) is of extreme importance and it determines the types of microorganisms capable of growing and damaging such foods, besides the tax which this growth causes. According to NAVARRO et al. (2001), the growth of molds in general is inhibited in products with the Aw below at 0.70 . Among the factors that influence the growth of microorganisms in foods, including grains, it is undisputed that the water levels are extremely important and determine the types of microorganisms able to grow and deteriorate such products. The water contents observed in the Table 4 is favorable to the development of the species of Aspergillus, Fusarium and Penicillium fungi, and insect pests. It was verified in an increase in the contamination along the flow production.

Table 4 - Water contents (\% w.b.), average number of insects, mites and fungi in samples collected from different areas of receiving, storage and feed production

\begin{tabular}{|c|c|c|c|c|}
\hline Sectors & $\begin{array}{c}\text { Water content } \\
(\% \text { w.b. })\end{array}$ & $\begin{array}{c}\text { Insects } \\
\left(\mathbf{N}^{\mathbf{0}} .\right)\end{array}$ & $\begin{array}{l}\text { Mites } \\
\left(\mathbf{N}^{0} .\right) \\
\end{array}$ & $\begin{array}{c}\text { Fungi } \\
\left(\text { CFU.g }{ }^{-1}\right)\end{array}$ \\
\hline Hopper corn & 14.10 & $4.0^{ \pm} 1.0$ & $3.0^{ \pm} 1.2$ & $2.0 \times 10^{2}$ \\
\hline Hopper flours & 13.50 & $3.0^{ \pm} 1.0$ & $4.0^{ \pm} 1.5$ & $3.7 \times 10^{2}$ \\
\hline Storage corn & 13.10 & $14.0 \pm 3.0$ & $12.0 \pm 3.6$ & $5.2 \times 10^{3}$ \\
\hline Storage flours & 13.06 & $4.0 \pm 2.0$ & $9.0 \pm 2.7$ & $3.9 \times 10^{3}$ \\
\hline Mash feed & 10.50 & $3.0^{ \pm} 1.0$ & $12.0 \pm 3.4$ & $2.4 \times 10^{2}$ \\
\hline Pellet feed & 10.90 & $2.0 \pm 1.0$ & $2.0 \pm 1.3$ & $1.2 \times 10^{1}$ \\
\hline
\end{tabular}

The fungi colonies presence in the products analyzed may represent a risk to the animals fed, when the mycotoxins production occurs (CORADI et al., 2011b). Contamination of aflatoxins in poultry feed can cause reductions in the activity of pancreatic enzymes and decreased bile concentration, increased incidence in the sciatic nerve injury, and antagonism in the metabolism of vitamins, proteins and amino acids, lipids and carbohydrates, coenzymes or acting on complex enzyme, mainly in the liver and affect the chemical structure of DNA. The largest damages caused by the insects in the grains happen during the storage period 
(Table 4) that could cause partial deterioration or total of the grains and the occurrence of the infestations.

The contaminations in the grains show great acting in temperatures of $23{ }^{\circ} \mathrm{C}$ to $35^{\circ} \mathrm{C}$ and that the moisture content of the grains that to favor the development of insects is $12 \%$ to $15 \%$, approximately. However, the insects infestation can be associated either with the not use adequate of the Good Manufacturing Practice (GMP), cleaning and sanitation system. For example, the insects can enter feed mills through while open the doors and windows. In addition, a careful inspection of the mill external and internal will reveal potential entryways, and these should be sealed or closed. This may not always be possible, but an alternative is the use of air curtains above open doors prevents insect entry by creating positive pressure airflow near the doors. Options like the use of plastic strips may also minimize insect entry. Broken windows should be screened with mesh screens (84 micrometer openings), and damaged mesh screens should be replaced with new ones. Bulk-stored grain or bagged grain should be inspected at the time of receipt and after storage at monthly intervals for signs and presence of the insects.

Measurement of grain temperatures within silos and round metal bins provides an indirect measure of insect activity, because insects can cause dry grain heating resulting in temperature increases of $42.2{ }^{\circ} \mathrm{C}$. Bulk-stored grain or pelleted feed in silos or bins should be sampled with vacuum probe, grain trier or deep bin cup probe to estimate absolute insect densities. If bulk or bagged grain is stored for more than a month, infestations can be monitored using perforated probe traps a method that provides relative estimates of pest density. The traps capture randomly moving insects within the grain mass, and have a high probability of detection because they work 24 hours a day and 7 days a week, unlike absolute sampling methods. It should be borne in mind that traps are monitoring tools and not tools to remove insects from infested grain. If live insects are present, the grain should be fumigated with phosphine to kill all species and stages of insects.

The use of air tight structures or cocoons is an excellent tool for those feed manufacturers that are organic or do not have pesticide products approved for admixing with grains. Oxygen levels below $2 \%$ are lethal to insects and mites, and also discourage other aerobic organisms (DOWDY and FIELDS, 2002). These air tight structures also come with a facility to connect to a vacuum pump to reduce oxygen levels below $2 \%$. Bagged materials should be sampled with spear samplers or scoops and the contents sifted to determine infestations. The seams of bags should be carefully inspected for insects or webbing caused by moth larvae. The dump pits and horizontal screw conveyers should be inspected for insect 
activity, and should be cleaned regularly to remove grain residues. Insects within the mill can be determined through visual inspections or by use of special trapping devices. A minimum of 30 traps in different areas of the mill is a good starting point (SUBRAMANYAM et al. 2005). These traps should be checked biweekly and the types and numbers of insects captured should be enumerated (Table 6). There are sticky traps with lures for flying insects, especially some species of beetles and all moths associated with stored products. These traps should be hung at eye level for easy inspection. Whether or not a trap captures an insect is based on insect behavior and environmental conditions that trigger insect movement.

Sanitation, both outside and inside silos, bins, and feed manufacturing plants is the most important technique. The grounds and mill perimeter should be devoid of any vegetation and food product spills, and should be paved. This eliminates harborages and creates an unfavorable environment for pests. The roof should be inspected regularly for proper drainage and for any accumulations of product, which may have leaked from bucket elevators, cyclones, exhausts, or other equipment positioned on, or passing through, the plant roof. Leaking equipment should be repaired and product accumulations removed. Storage facilities receiving grain should be thoroughly cleaned and treated with an approved pesticide to control residual insect populations to prevent contamination of insect-free grain loaded into the facility. Regularly scheduled cleaning is important in the receiving, handling, and storage areas. Cleaning frequency should be based on the observed need, and may vary depending on the intensity of operations. As a general rule of thumb, walls, overhead areas, and equipment interiors should be cleaned at least once each month to prevent insect development. Dead spots in handling equipment can become breeding areas for insects unless they are cleaned monthly to break the insect developmental cycle. Increased emphasis on cleaning and the use of insecticide sprays, fogs and/or mists in plant spaces has been used to supplement general fumigations as an alternative to spot fumigations.

The results for mites contamination were similar with those observed in insect samples. The problem occuring most was in storage system, mainly for corn storage. The mite population increased considerably in the storage step, passing to decrease in the running production, and arriving to low contamination in the final pellet feed. The problem with corn contamination in the storage system showed the reflex in final mash feed (Table 4). Mites are eight legged creatures, and several species of mites are associated with feed mills and feed materials. Mites thrive under humid conditions (80-90\% humidity), and can develop at temperatures as low as $9^{\circ} \mathrm{C}$, whereas stored-product insects generally fail to develop at temperatures below $15^{\circ} \mathrm{C}$. Egg-to-adult development of mites takes 2-3 weeks whereas that of 
stored-product insects takes $30-40$ days at optimum conditions $\left(28-32^{\circ} \mathrm{C}\right)$. The best method to manage mites may include the use of cocoons, application of residual products, fumigation, or managing moisture in the feed mill. Modified atmospheres (low oxygen atmospheres by use of carbon dioxide or nitrogen) also offers a solution for mite infestation in packaged and tightly sealed packaged feed products.

Observing the results in the Table 5, states that the feed mill adopts a measured control over the rodents infestation, but in most situations they are not free from problems of contamination in the products, once detected the presence of rodents in the interior and around the factories. According to MATIAS et al. (2002), the signs of rodent infestation is considered low when it is observed tracks, gnawing, friction grease stains and a few stools; average infestation when you look at just a few tracks and gnawing, droppings in several places, and high infestation when they are multiple tracks, gnawing and grease stains with various rodents seen the night and some during the day. The same author mentions that the infestation from 1 to 5 rodents is considered low, from 6 to 15 rodent infestations and average 16 to 29 high rodent infestations. Rodent consumption of stored food and grain and damage to storage structures and containers, and indirect losses caused by spillage, spoilage, or contamination that results in condemnation or rejections of shipments are important economic and public health problems worldwide.

Table 5 - Rodents infestation in the external and internal areas of receiving, storage and production of feed

\begin{tabular}{llllccc}
\hline Sectors & Feces & Urine & Hair & $\begin{array}{c}\text { Consumed } \\
\text { baits }\end{array}$ & $\begin{array}{c}\text { Live } \\
\text { rodents }\end{array}$ & $\begin{array}{c}\text { Dead } \\
\text { Rodents }\end{array}$ \\
\hline Hopper corn & High & Present & High & 3 & 12 & 5 \\
Hopper flours & High & Present & High & 3 & 9 & 4 \\
Storage of corn & Medium & Present & High & 25 & 20 & 12 \\
Storage of flours & Medium & Present & Medium & 7 & 10 & 4 \\
Pre cleaning of corn & Medium & Present & Medium & 4 & 6 & 4 \\
Drying of corn & Medium & Present & Medium & 6 & 5 & 3 \\
Feed production & High & Present & Medium & 30 & 14 & 10 \\
\hline
\end{tabular}

The great diversity of rodent species, storage structures, and environmental conditions and the difficulty in estimating incremental or indirect losses help mask the economic impact of the problem. Since most rodent species involved in stored product damage are nocturnal, heavy infestations may persist unnoticed without careful inspection of stores or premises. In many situations, careful grain handling procedures, indoor and outdoor sanitation, immediate disposal of spillage and garbage, frequent inspection for rodent signs, and maintenance control programs are important ways to prevent the development of more serious and difficult problems. The high infestation of birds is always very evident in feed mills (Table 6). 
Table 6 - Infestation of birds in the external and internal areas of receiving, storage and production

\begin{tabular}{lcccc}
\hline Sectors & Feces & Feathers & Live birds & Dead birds \\
\hline Hopper corn & Medium & Medium & 6 & 7 \\
Hopper flours & Medium & Medium & 5 & 8 \\
Storage of corn & High & Medium & 14 & 4 \\
Storage of flours & High & Medium & 13 & 6 \\
Pre cleaning of corn & High & Medium & 16 & 8 \\
Drying of corn & Medium & Low & 4 & 2 \\
Feed production & Medium & Low & 5 & 7 \\
\hline
\end{tabular}

During the evaluation it was found the presence of feathers and feces in all sectors of industry, dead birds were found in elevator pits, bins and storage of corn, bran and feed, giving signals would be contaminated with mycotoxins. An integrated pest management plan is necessary to tackle a bird problem. There are five basic approaches in managing a bird population. These include survey, sanitation, exclusion and habitat alteration, repellents, and population reduction. Surveys are necessary to identify the bird species and to study their activity patterns. Sanitation involves limiting or reducing access to food, water and shelter, in addition to regular removal of nests. Frequent clean up of spilled grain outside feed manufacturing plants is difficult and impractical. However, an effort should be made to change practices that cause grain spillage. Cleaning clogged drains, leaks, and standing water on roofs will help remove a water source. Persistent destruction of nests will greatly reduce populations of sparrows and pigeons.

The objective of exclusion is to deny access to enter or use the building as a nesting, roosting or loafing site. Plastic bird nets, covers, or ramps can be used to keep birds out of certain areas. The way a building is designed will provide harborage for large populations of birds. Therefore, building modifications play an important role in bird management. Various kinds of repellents are available that can either scare the birds away or make it difficult for them to use the building as a nesting or roosting site. Different wires, such as porcupine wires, bird barrier coils, spikes, electrically charged wires, and piano string have been used to physically prevent birds from nesting and roosting. Sticky substances have been used, in certain situations, to repel birds. Population reduction is mainly achieved by the use of toxic baits, traps, and sometimes, by shooting. Toxic baits have to be used with caution, as they may prove hazardous to non-target domestic animals or wildlife. Avitrol and Starlicide are two commonly used baits for pigeons and starlings. Prebaiting with untreated grain will improve the efficacy of toxic baits. Pigeons and sparrows can sometimes be trapped near their loafing or feeding sites. 


\title{
4 Conclusions
}

The microbiological characteristics of the ingredients used to manufacture poultry feed does not meet the requirements of the Good Manufacturing Practices Manual, if not improved can contaminate the final products and, therefore, possible cause diseases to animals and reduced productivity. Biological and microbiological contamination in the outdoors at the reception, handling and storage of products was considered as critical points in the manufacturing line feed. The adoption of preventive measures against rodents and birds should be implemented in feed mill. First, cleaning and hygiene sectors of food and no exposure outside the desirable areas are attractive ways to avoid. The installation of traps to catch rodents, protect the outer areas of the mill and remove dirt, bushes near the feed industries are some alternatives to prevent infestations.

\section{Acknowledgements}

The authors would like to thank the CAPES Foundation (Brazilian Ministry of Education), Department of the Agricultural Engineering and Federal University at Viçosa for its financial support.

\begin{abstract}
Resumo
Com base nos princípios APPCC, o objetivo deste trabalho foi identificar os pontos críticos de controle em uma fábrica de ração com capacidade real de produção de 1000 t.dia ${ }^{-1}$ localizado no sudoeste do Brasil, avaliando a presença de pássaros, roedores, insetos, ácaros e fungos nos produtos, subprodutos e ambientes internos e externos da indústria. As amostragens de produtos e instalação de armadilhas foram às técnicas utilizadas para o controle. O recebimento, a pré-limpeza, a secagem e o armazenamento de milho, bem como a dosagem e mistura da ração foram às etapas caracterizadas como pontos críticos, em função dos altos índices de contaminação. Pássaros e roedores foram os principais contaminantes observados durante o processo de produção da indústria de ração, no entanto, o alto número de insetos e colônias de fungos encontrados nos produtos, significou os maiores riscos de contaminação para o produto final. Em conclusão, o uso de boas práticas de armazenagem e processamento, instalação de armadilhas, o uso de processos intensos de limpeza e sanitização são alternativas imediatas e eficientes no controle de contaminações em fábricas de rações.
\end{abstract}

Palavras-chaves: pássaros; fungos; insetos; ácaros; roedores.

\section{References}

ARBOGAST, R. T.; KENDRA, P. E.; MANKIN, R. W.; MCGOVERN, J. E. Monitoring insect pests in retail stores by trapping and spatial analysis. Journal of Economical Entomology, v. 93, p. 1531-1542, 2000. http://dx.doi.org/10.1603/0022-0493-93.5.1531 
BATA, D.; DROSINOS, B. D.; ATHANASOPOUlOS, P.; SPATHIS, P. Cost of GHP Improvement and HACCP Adoption of an Airline Catering Company. Food Control. p. 414 - 419, 2006.

BOLAND, M.; HOFFMAN, D. P.; FOX, J. A. Post implementation Costs of HACCP and SSOP's in Great Plains Meat Plants. Journal of Food Safety, v. 21, p. 195-204, 2001. http://dx.doi.org/10.1111/j.17454565.2001.tb00318.x

BRASIL. Portaria ${ }^{\circ}$. 1428, de 26 de novembro de 1993. Estabelece a necessidade da melhoria da qualidade de vida decorrente da utilização de bens, serviços e ambientes oferecidos à população na área de alimentos. Diário Oficial, Brasília, nº. 229, 1993, p. 18415.

BRASIL. Portaria $n^{\circ} .845$ de 8 de novembro de 1976. Estabelecem as especificações para a padronização, classificação e comercialização interna do milho. Dário Oficial, Brasília, nº.787, 1976, p. 19756.

BRASIL. Ministério da Agricultura e Reforma Agrária. Regras para Análise de Sementes. Brasília, DF, 2009.

CODEX ALIMENTARIUS. Code of practice on good animal feeding. Food and Agriculture Organization and World Health Organization, Rome. p. 1-12. 2004.

COLATORE, C.; CASWELL, J. A. The Cost of HACCP Implementation in the Seafood Industry: A Case Study of Breaded Fish. In: UNNEVEHR, L. J. The Economics of HACCP: Studies of Costs and Benefits, St. Paul: Eagan Press, 2001, p. 45-68.

CORADI, P. C.; LACERDA FILHO, A. F. de; MELO, E. C. Análise de Perigos e Pontos Críticos de Controle (APPCC) no processo de fabricação da ração. Revista Eletrônica Nutritime, v. 6, p. 1098-1102, 2009.

CORADI, P. C.; LACERDA FILHO, A. F. de; MELO, E. C.; CHAVES, J. B. P. Qualidade dos Ingredientes utilizados na Indústria de Ração para Aves no Estado de Minas Gerais, Brasil. In: IX Congreso Latino Americano y Del Caribe de Igeniería Agrícola (CLIA) e XXXIX Congresso Brasileiro de Engenharia Agrícola (CONBEA), 2010, Vitória, ES. A Engenharia Agrícola e o Desenvolvimento das Propriedades Familiares. Jaboticabal, SP: Jaboticabal: Sociedade Brasileira de Engenharia Agrícola, 2010.

CORADI, P. C.; LACERDA FILHO, A. F.; MELO, E. C. Quality of raw materials from different regions of Minas Gerais State utilized in ration industry. Revista Brasileira de Engenharia Agrícola e Ambiental (Online), v. 15, p. 424-431, 2011a. http://dx.doi.org/10.1590/S1415-43662011000400015

CORADI, P. C.; LACERDA FILHO, A. F.; MELO, E. C.; CHAVES, J. B. P. Contagem de Colônias de Fungos em Subprodutos de Origem Animal Processados no Estado de Minas Gerais. In: XL Congresso Brasileiro de Engenharia Agrícola (CONBEA), 2011, Cuiabá, MT. Geração de Tecnologias Inovadoras e o Desenvolvimento do Cerrado Brasileiro. Jaboticabal, SP: Sociedade Brasileira de Engenharia Agrícola (SBEA), 2011b. v. 1. p. 1-4.

DHINGRA, O. D.; SINCLAIR, J. B. Basic plant pathology methods. 2. ed. Boca Raton: CRC Press, 1995, $434 \mathrm{p}$.

DOWDY, A. K.; FIELDS, P. G. Heat combined with diatomaceous earth to control the confused flour beetle (Coleoptera: Tenebrionidae) in a flour mill. Journal of Stored Products Research, v. 38, p. 11-22, 2002. http://dx.doi.org/10.1016/S0022-474X(00)00037-0

FAO. Food and Agriculture Organization of the United Nations. Manual of the application of the HACCP system in mycotoxin in prevention and control, Roma, 2001, 118p.

HOORNSTRA, E.; NORTHOLT, M. D.; NOTERMANS, S.; BARENDSZ, A. W. The use of quantitative risk assessment in HACCP. Food Control, v. 12, p. 229-234, 2001. http://dx.doi.org/10.1016/S09567135(01)00019-6

HUGHES, A. M. The mites of stored food and houses. London, Min. Agric. Fish. Food, 1976, 400p.

LORINI, I.; MIKE, L. H.; SCUSSEL, V. M. Grain storage. Campinas: IBG (Institute Bio Genesis), 2002 , 1000p. 
MATIAS, R. S.; OLIVEIRA, W.; STEDILE, V. M. Roedores associados aos grãos armazenados. In: LORINI, I, MILJE, L. H., SCUSSEL, M. V. Grãos armazenados, Campinas: BioGenezis Instituto, 2002, p. 252-287.

NAVARRO, S.; NOYES, R. T.; ARMITAGE, D.; MAYER, D. E. The mechanics and physics of modern grain aeration management. Ed. CRC press, 2001, 624p.

REMPE, J. Manufacturing operations, In: MCELLHINEY R. R. Feed manufacturing technology IV. American Feed Industry Association, Inc., Arlington: VA. 1994. 69p.

RESANOVIĆ, R.; SINOVEC, Z. Presence of aflatoxin B1 tissue residues influenced by different route of modified clinoptilolite application. 28th Congress WVPA, Anais...., 2005, p. 352-353.

RILETT, R. O.; WEIGEL, R. D. A winter survey of Coleoptera in feed and flour mill. Journal of Economical Entomology, v. 49, p. 154-156, 1956.

ROESLI, R.; SUBRAMANYAM, B. H.; FAIRCHILD, F. J; BEHNKE, K. C. Trap catches of stored-product insects before and after heat treatment in a pilot feed mill. Journal of Stored Products Research, v. 39, p. 521540, 2003. http://dx.doi.org/10.1016/S0022-474X(02)00058-9

ROMANO, D.; CAVICCHI, A.; ROCCHI, B.; STEFANI. G. Exploring costs and benefits of compliance with HACCP regulations in the European meat and dairy sectors. Acta Agriculturae Scandinavica, v. 2, p. 52-59, 2005.

SCOTT, V. N., STEVENSON. K. E. HACCP: a systematic approach to food safety. Food Products Association, Washington, D.C., 2006.

SCHOEFF, R. History of the formula feed industry. In: MCELLHINEY, R. R. Feed manufacturing technology IV. American Feed Industry Association, Inc., Arlington: VA. 1994.

SINOVEC, Z.; PALIĆ, T.; IVETIĆ, V.; ZNAČAJ MIKOTOKSIKOZA U VETERINARSKOJ MEDICINI, Clinica veterinária, p. 167-177, 2000.

SUBRAMANYAM, B. H.; ROESLI, R.; BRUESCH, J.; MENON, A. Sanitation and pest management. In: SCHOFIELD, E. K. Feed manufacturing technology V. American Feed Industry Association, Arlington: Virginia, 2005. p. 415-431.

YUAN, H. Cost-and-Benefit Analysis on Adoption of HACCP Certification for Chicken Manufacturers: A Case Study by Corporation Department in Beijing Dafa Chia Tai Co., 2006. Tese (Sch. Agr. and Rur. Dev. Renmin) - University of China.

Submetido em 27 dez. 2011, Aceito para publicação em 26 dez. 2012. 